\title{
アナログテレビジョンの音声信号による地上デジタルテレビ ジョン放送信号への同一チャネル干渉実験
}

Experimental Evaluation of Analog Television Sound Signal's Co-channel Interference to Digital Terrestrial Television Signal

正会員 永 塚 守 ${ }^{\dagger}$, 正会員 都竹 愛一郎 ${ }^{\dagger}$

Mamoru Nagatsuka ${ }^{\dagger}$ and Aiichiro Tsuzuku ${ }^{\dagger}$

あらまし 地上デジタル放送信号に対するアナログテレビジョン信号の干渉について, 特にアナログ音声信号 に着目した実験を行った，映像信号に比べて, 音声信号の干渉の影響は大きく, 音声の変調信号の違いにより, 干渉特性に差が生じることを明らかにした。

キーワード：地上ディジタルテレビジョン放送, OFDM, 同一チャネル干渉, 混信保護比

\section{1. ま え がき}

我が国の地上デジタルテレビジョン放送の方式について は，すでに電気通信技術審議会から答申 ${ }^{1)}$ が行われた。現 在は, 地域ごとのチャネル割当と, パラメータの選択の検 討作業などが進められている。

アナログテレビジョン信号からデジタルテレビジョン信 号への同一チャネル干渉については, (社)電波産業会を中 心とした実験 ${ }^{2)}$ が行われ，答申策定時の資料にも用いられ た。この実験報告によれば，アナログ映像信号について， その変調内容が干渉特性に大きな影響を与えないことは確 認されているが, 音声信号については言及されていない.

本研究では, 特にアナログの音声信号に着目し, 映像信 号と比較した相対的な干渉の強さを調べ, 変調内容による 干渉特性の差を測定する実験を行った。

\section{2. 実 験 方 法}

実験システムは，図10ような構成とした。実験に用い たディジタル信号のパラメータは, 表 1 の通りである. 誤 り訂正符号は内符号のみを用いた。

干渉源となるアナログ信号は, CATV 用の変調器を用 いて発生させた。使用チャネルはC 50 で, 規格上の周波 数は図 1 に示した通りである。しかし, 実際には数十 $\mathrm{Hz}$ のずれが生じた。

デジタル信号とアナログ信号の間の周波数関係が正確で

2000 年 7 月 27 日受付, 2000 年 9 月 14 日再受付, 2000 年 9 月 26 日採録 †郵政省通信総合研究所

（广 184-8795 小金井市貫井北町 4-2-1，TEL 042-327-6932）

$\dagger$ Communications Research Laboratory, MPT

(4-2-1 Nukui-kita, Koganei-shi, Tokyo 184-8795, Japan)

$1598(120)$
あれば，アナログ信号の映像搬送波と OFDM のキャリヤ のうちの 1 本(帯域下端から数えて 901 本目)の周波数は一 致する. 今回の実験では, これらの間の周波数差が $5 \mathrm{~Hz}$ 以下となるよう, デジタル信号用アップコンバータのロー カル周波数を調整した。なお，このときのアナログ音声搬 送波周波数は，規格上の周波数(映像搬送波より $4.5 \mathrm{MHz}$ 高い值)に比べ, $-56 \mathrm{~Hz}$ からー $53 \mathrm{~Hz}$ の範囲にあった.

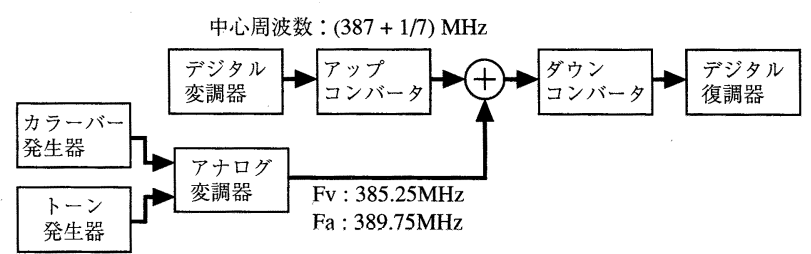

図 1 実験系統図

Block diagram of test system.

表 1 使用したデジタルテレビジョン信号のパラメータ Parameters of digital television signal.

\begin{tabular}{c|c}
\hline モード & Mode 3 \\
\hline キャリヤ数 & 5617 \\
\hline 帯域幅 & $5.57 \mathrm{MHz}$ \\
\hline 変 調 & $64 \mathrm{QAM}-\mathrm{OFDM}$ \\
\hline 有効シンボル長 $T_{e}$ & $1008 \mu \mathrm{S}$ \\
\hline ガードインタバル $T_{s}$ & $T_{e} / 4$ \\
\hline キャリヤ間隔 & $1 / T_{e}(992.063 \cdots \mathrm{Hz})$ \\
\hline 内符号 & 畳込み符号 $($ 符号化率 $7 / 8)$ \\
\hline 時間インタリーブパラメータ & 1 \\
\hline
\end{tabular}

映像情報メディア学会誌 Vol. 54, No. 11, pp. 1598〜1601（2000） 
無線設備規則第 37 条の 3 によれば, 地上放送において は土1 kHz の偏差が許容されており, この範囲内の值で ある。

アナログ映像信号の変調に用いた画像は, カラーバーと した。アナログ音声信号の変調には, 正弦波のテストトー ンを用いた。

\section{3. 音声信号による干渉の強さ}

まずデジタル信号が受ける干渉のうち，アナログ音声信 号が関与する割合を調べる実験を行った。この実験では, 音声変調信号に $1 \mathrm{kHz}$ の正弦波を用い, 変調度を $100 \%$ (周波数偏移 $\pm 25 \mathrm{kHz}$ ) とした. デジタル信号の平均電力 とアナログ信号の映像同期尖頭電力の比を $D / U$ として定 義し, これを変化させて測定した.アナログの映像・音声 を同時に使用した条件(映音同時) と, 映像信号のみ, 音声 信号のみの 3 条件の実験を行った。すべての条件で, 誤り 訂正符号を用いない BER を測定したほか, 映音同時の場 合には，誤り訂正を行った状態でも測定した。

映音比(アナログの映像同期尖頭電力と音声信号電力の 比)を $6 \mathrm{~dB}$ とした場合の結果を図 2 に示した。まず，映 音同時での誤り訂正後の特性については, BER が $2 \times 10^{-4}$ となる $D / U$ が約 $26 \mathrm{~dB}$ となった. 中原らの Mode 2 での 実駼報告2)では $25 \mathrm{~dB}$ であり，ほぼ同じ結果である。

次に, 誤り訂正を行わない場合の各 $D / U て ゙ の B E R の$ 測定結果に扔いて, 映像のみの值と音声のみの値を合計す ると，映音同時の值と一致することが確認できる．音声信 号と映像信号は, 各々異なる OFDM キャリヤ群に干渉を 与えているためである.

ここで， $D / U$ が $26 \mathrm{~dB}$ の測定結果に注目する. 映音同 時の BER は $2.4 \times 10^{-3}$, 音声のみ条件では $1.8 \times 10^{-3}$ で ある。これらの值から計算すると, 発生しているビットエ ラーのうち，75\%が音声信号に起因したものということに なる. 音声信号電力は, 映像信号電力に比べて $1 / 4$ 亿過ぎ ないが，与えるビットエラーの数は 3 倍であった。映像信 号では，スペクトル的に特定の周波数にエネルギーが集中 し, OFDM の少数のキャリヤが影響を受けるが, 音声信 号は FM 変調のため, 近傍の多くのキャリヤが影響を受 け，結果的に影響が大きくなるものと考えられる。

以上のように, 音声信号の影響は相対的に大きいといえ る.この点から, 映音比を変えると, 映像信号を基準とす る $D / U$ が同じでも，干涉の程度が異なることが予想され る. 無線設備規則第 37 条の 4 によれば, 音声信号電力の 映像信号電力に対する比は $15 \%$ 以上 $35 \%$ 以下と規定され ている。これは，映音比の表現では $8.2 \mathrm{~dB}$ から $4.6 \mathrm{~dB}$ の範囲に相当し, $3.6 \mathrm{~dB}$ の範囲が許容されることになる. そこで, 映音比をこの範囲で変化させ, 映音同時の誤り訂 正後の BER 特性がどの程度変化するかを調べる実験を行 った。結果を図 3 に示す. BERが $2 \times 10^{-4}$ となる $D / U$ を所要 $D / U$ とすると, 映音比 $4.6 \mathrm{~dB}$ での所要 $D / U$ は,

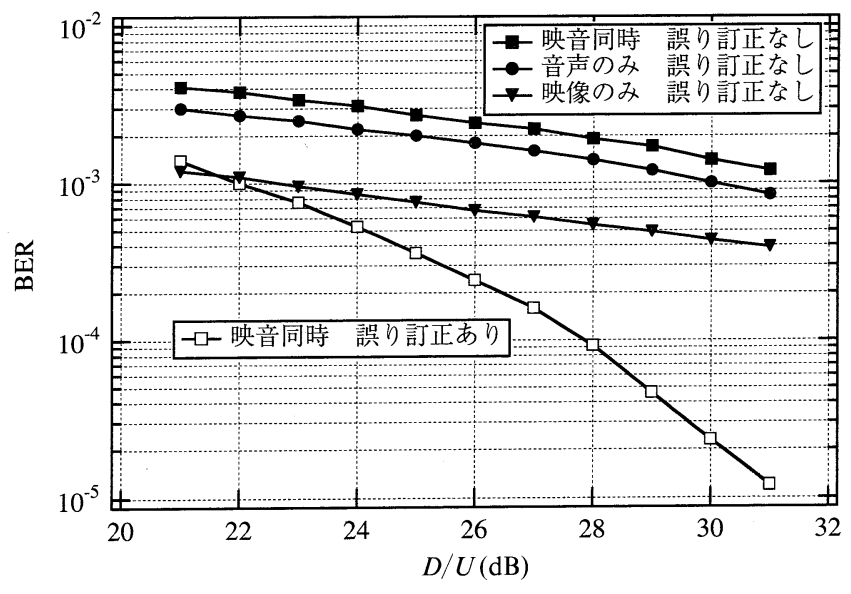

図 $2 D / U$ 亿対する BER 特性 DU ratio vs. BER characteristics.

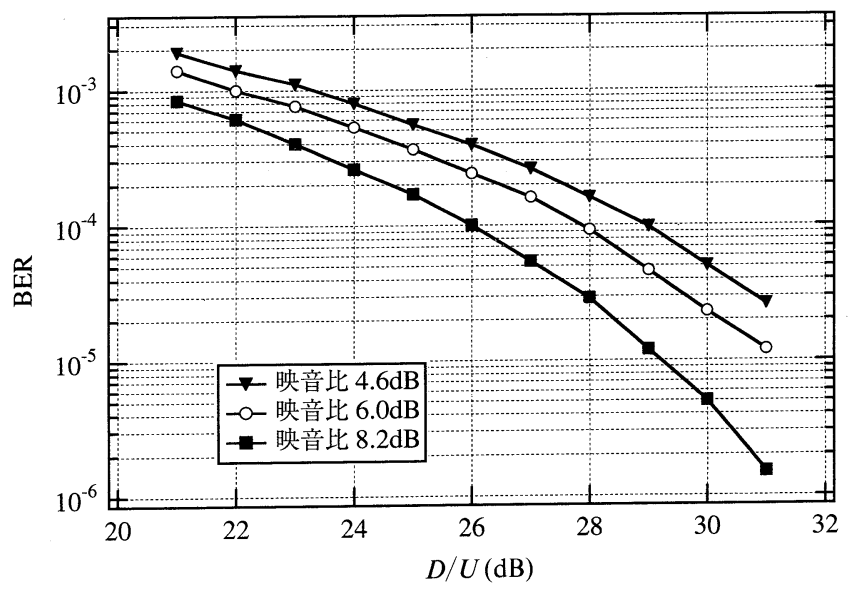

図 3 映音比と BER 特性の関係

Video/sound power ratio vs. BER characteristics.

映音比 $8.2 \mathrm{~dB}$ の場合に比べ約 $2.9 \mathrm{~dB}$ 大きい.もし, $D / U$ の算定を音声信号で行うなら, 両者の間の所要 $D / U$ の差は, $3.6 \mathrm{~dB}$ から $2.9 \mathrm{~dB}$ を差し引いた $0.7 \mathrm{~dB}$ となる.このことからは, 映音比の変化の影響を受けにく い $D / U$ の表現をするためには, アナログ信号の電力とし て, 映像信号ではなく音声信号のものを使うことが適切と いえる。

\section{4. 音声信号の性質と干渉}

\section{1 変調度の影響}

アナログの音声信号は FM 変調であるため, 変調度を 変えると信号の帯域幅が変化する. 変調度を変化させるこ とによる BERへの影響を調べた。

$D / U$ を $26 \mathrm{~dB}$ (アナログ信号の電力には映像同期尖頭電 力を用いて算出した。 以下同様) とし, 映音比は $6 \mathrm{~dB}$ と した. $1 \mathrm{kHz}$ 正弦波の音声変調信号のレベルを変え, 変 調度によるBERの变化を測定した。結果を図 4 に示す. グラフには，映音同時で誤り訂正なしの場合と，ありの場 合の結果を示した。な打横軸は, 変調度 $100 \%$ 基準にし 


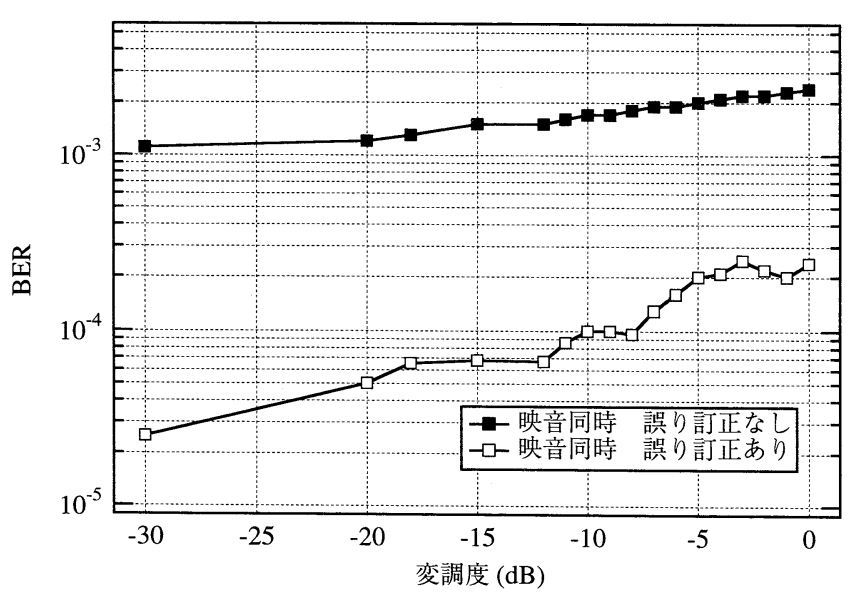

図 4 変調度に対する BER 特性 Modulation factor vs. BER characteristics.

た $\mathrm{dB}$ 表示である.

おおむね，変調度が小さくなるにつれ，BERが小さく なることが確認できる。変調度が小さくなって帯域幅が狭 くなると, 音声信号の干渉を受ける OFDM のキャリヤ数 は少なくなる。一方で, 音声信号の電力は一定であるか ら, OFDM のキャリヤ 1 本当たりの受ける干渉の度合い は大きくなると考元られる。これらの相反する効果が拈抗 するため, 変調度と BER の間の単純な関係は得られない が, 変調度が大きく変化した場合, 影響を受けるキャリヤ の数が減少する効果の方が大きく, BER が減少すると思 われる。

誤り訂正ありの結果を見ると, 変調度 $3 \%(-30 \mathrm{~dB})$ の ときの BER は，100\%のときに比べ $1 / 10$ 程度となること がわかる.アナナログの音声変調信号のレベルが, デジタル 信号への干渉に大きな影響を与えていることが確認でき る.

\section{2 变調信号周波数の影響}

次に, 変調信号の周波数による, 干渉特性への影響を検 討する。

$D / U$ を $26 \mathrm{~dB}$, 映音比を $6 \mathrm{~dB}$, 変調度を $100 \%$ と, 変調信号の周波数による BER の変化の測定結果を図 5 に 示した。映音同時で, 誤り訂正を使用しない結果と, 使用 した結果である。なお，アナログテレビジョンの音声信号 には $75 \mu \mathrm{s}$ のプリエンファシスが施されるため, 周波数ご とに変調器への入力信号レベルの調整を行い, 変調度を一 定に保った。

周波数により BER は変化する. 誤り訂正を行った結果 では, 測定した周波数範囲内で, およそ8倍の差が生じて いた. BER が最大值を示すのは $3 \mathrm{kHz}$ の場合であった。 そのほか, $6 \mathrm{kHz} や 9 \mathrm{kHz}$ では, 近傍の周波数に比べ, 特㳘響が大きくなっていることがわかる。

これは, デジタル信号のスキャッタドパイロット (SP) が選択的に妨害されるためと考えられる.アナログの音声 信号キャリヤに相当する周波数は, OFDM の SP の置か

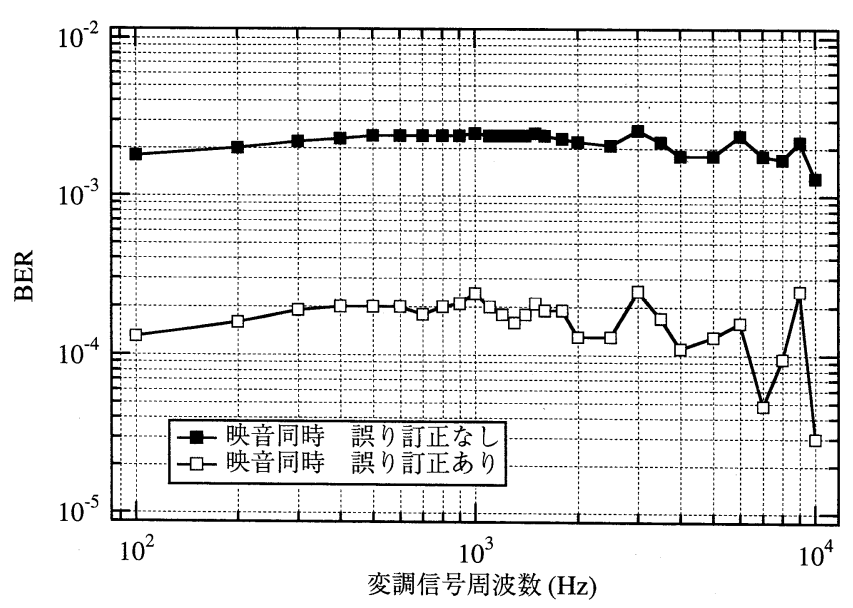

図 5 変調信号周波数に対する BER 特性 Frequency of modulating signal vs. BER characteristics.

れるキャリヤの周波数でもある. SP は 3 キャリヤごとに 配置されている。すなわち, 約 $3 \mathrm{kHz}$ 間隔である.

FM 変調のスペクトルでは, その中心周波数から変調周 波数の整数倍にあたる周波数に，エネルギーが集中する. 上で挙げた変調周波数のアナログ音声信号は, 約 $3 \mathrm{kHz}$ 間隔に配置された SPに，選択的に妨害を与えることが考 えられる.SP が妨害を受けると, シンボル判別の基準推 定に影響し，隣接するキャリヤの復調にも支障が出る。こ の影響を含めて考えると，SPでないキャリヤが同等の妨 害を受けた場合に比べ，影響が大きい．

以上のように, Mode 3 を使った上, 変調度 $100 \%$ 干 渉が最も大きくなる状態での実験を行うなら，音声変調信 号には $3 \mathrm{kHz}$ を用いる必要がある。ただし，アナログ信 号とデジタル信号の周波数関係が一致しない場合には, 結 果が異なることが予想される。この点に関する検討は，今 後の課題としたい.

\section{5. むすび}

アナログテレビジョン信号からデジタル方式への同一チ ヤネル干渉について実験を行い, アナログ音声信号の変調 内容に影響されることを示した。

アナログ信号を映像信号と音声信号に分けてその影響を 調べた。誤り訂正前のビットエラーのうち音声信号に起因 するものの割合が $3 / 4$ に上ることがあり，音声信号の影響 が映像信号に比べてきりことを確認した。したがって, 混信保護比としての $D / U$ の計算に扔いては, アナログ信 号の電力として音声信号の電力を用いることを提案した. 従来の映像信号同期尖頭電力を用いる方法に比べ, 映像信 号と音声信号の電力比が異なる妨害波に対しても，妨害の 度合いをより正確に反映する基準となることを示した。

その他, 変調度が大きい場合, また, 音声変調周波数が 特定の值をとる場合に，妨害が大きくなることを示した．

今後は, 映像や音声の内容が常に変化する実際のアナロ グ放送波を使うなど，より現実に即した実験を行う。また 
測定によって得られた知見を, 消失化軟判定復号 ${ }^{2)}$ の手法 に応用することについても検討する予定である。

\section{〔文献〕}

1）電気通信技術審議会答申, “地上デジタルテレビジョン放送方式の技術 的条件” (May 1999)

2）中原, 岡野, 黒田, 佐々木, 内海：“地上デジタルテレビジョン信号の干渉 特性”, 映情学誌, 53, 11, pp. 1585-1591 (Nov. 1999)

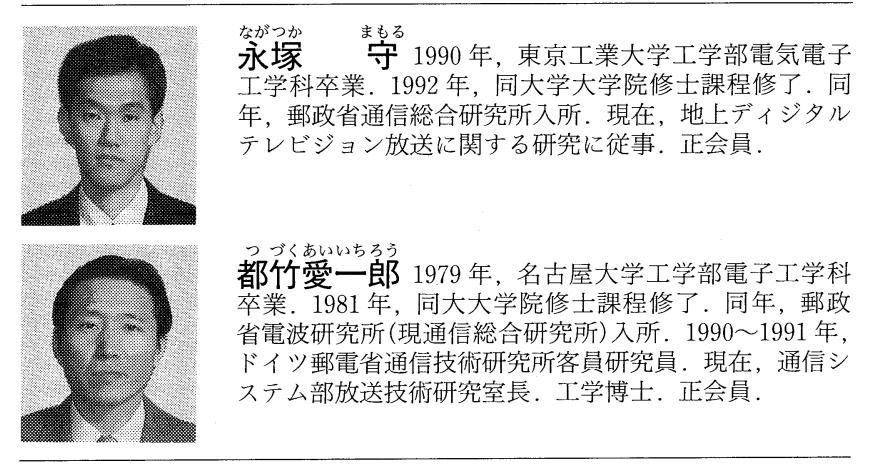

